\title{
The absorption and retention of nitrogen from leaf protein by infants recovering from malnutrition
}

\author{
By J. C. WATERLOW* \\ Medical Research Council Tropical Metabolism Research Unit, University of \\ the West Indies, famaica
}

(Received 3 fanuary 1962-Revised I4 Fune 1962)

In underdeveloped countries no source of protein can be neglected that is likely to be useful as human food. Duckworth and his colleagues have shown that leaf protein (LP) prepared by the method of Morrison \& Pirie (196r) has good nutritive value for chicks, rats and pigs (Duckworth \& Woodham, r96r; Duckworth, Hepburn \& Woodham, I96r). These results were encouraging enough to justify trials on human subjects. Balance studies were therefore made on Jamaican infants recovering from malnutrition.

To give LP as the sole source of nitrogen would not be realistic; it is more likely to be useful as one component of a vegetable protein supplement. In Jamaica the most readily available sources of protein, apart from green leaves, are legumes and coconuts. As a first step, however, LP was given in combination with milk protein. Dietary histories and surveys show that many Jamaican infants aged about I year receive an amount of protein from milk which, though inadequate, is not negligible - of the order of $0.5 \mathrm{~g} / \mathrm{kg}$ body-weight daily. The practical question therefore seemed to be: can leaf protein be used as a supplement to marginal quantities of milk? 'To answer it, mixtures were given providing daily 3-5 g protein $/ \mathrm{kg}$ body-weight, in which one-half to twothirds of the nitrogen was derived from LP and the remainder from milk.

Two kinds of control diet were needed: diets providing an equal intake of protein but derived entirely from milk; and diets providing a marginal intake of protein from milk, without supplementary leaf protein. As far as possible, each subject was used as his own control, but each kind of comparison could not be made with every patient.

The results obtained with low protein intakes are also of some interest in relation to the problem of protein requirements. This point is considered in more detail on p. 537 .

The criterion used in this work was that of $\mathrm{N}$ balance. In recent years balance studies and their interpretation have been subjected to much criticism, and some people have maintained that the method is of little or no value (Gordon \& Ganzon, 1959). Therefore it seemed necessary in the discussion to examine as closely as possible the validity of the conclusions drawn from these measurements.

* Present address: c/o Department of Chemical Pathology, St Mary's Hospital Medical School, London, W. 2. 


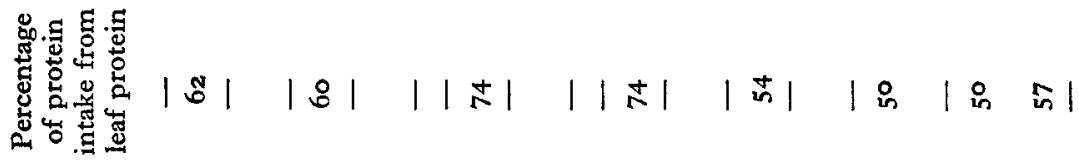

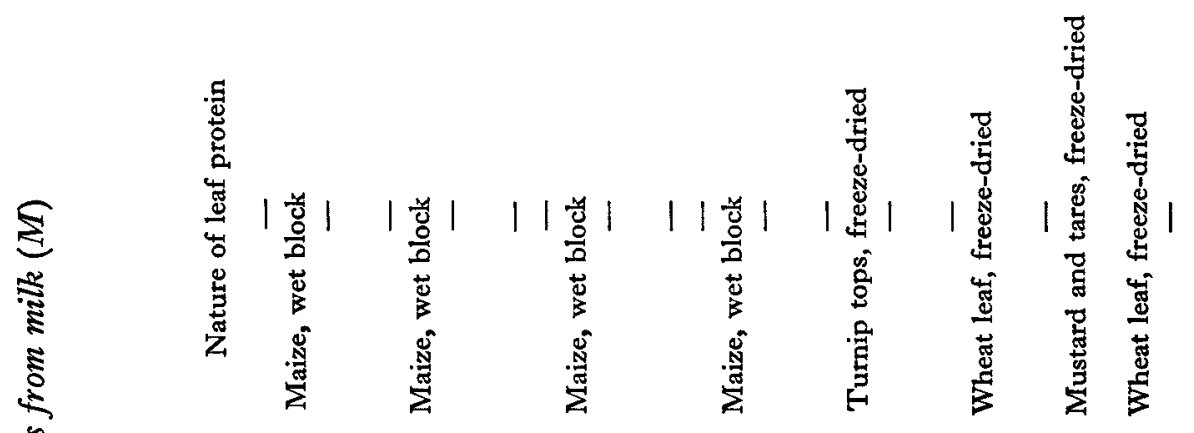

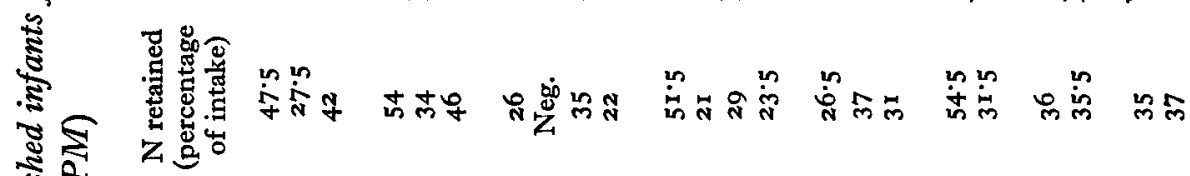

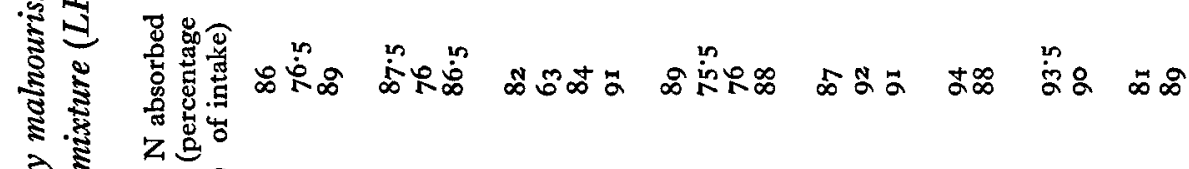
ते

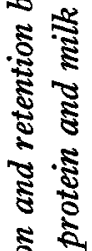

还 乙

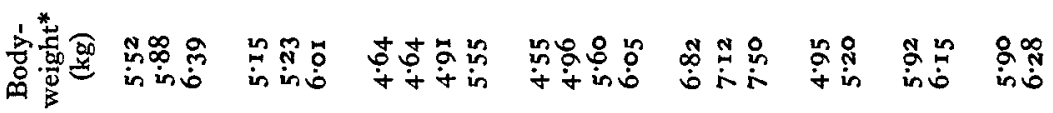
:

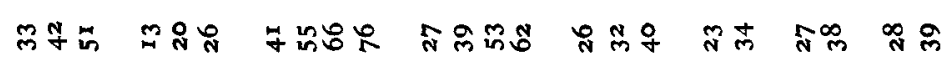

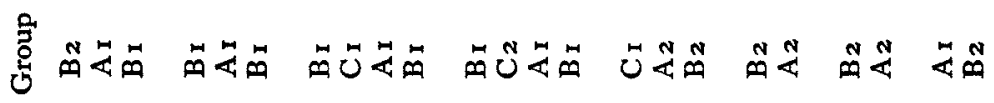

宸

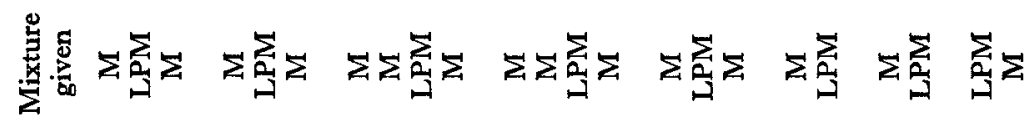

\begin{tabular}{|c|c|c|c|c|c|c|}
\hline 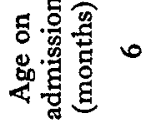 & $\approx$ & $m$ & $m$ & $\mp$ & ㅇ & $\approx$ \\
\hline 吾 & N & $m$ & + & in & 0 & $r$ \\
\hline
\end{tabular}


Vol. I6

Nutritive value of leaf protein

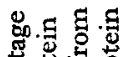

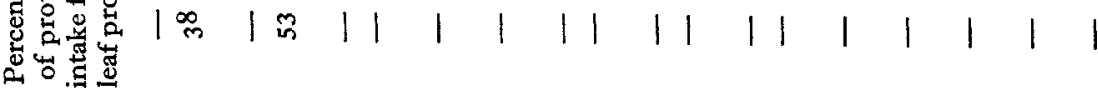

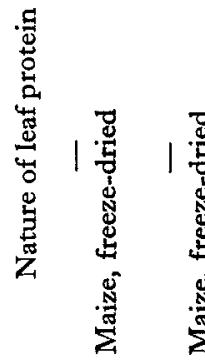

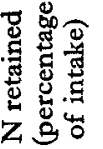

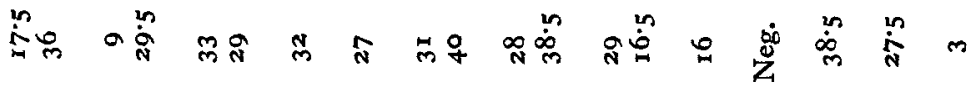

送

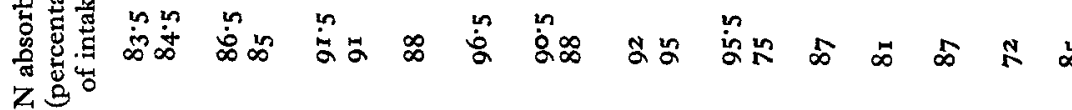

हु

電要

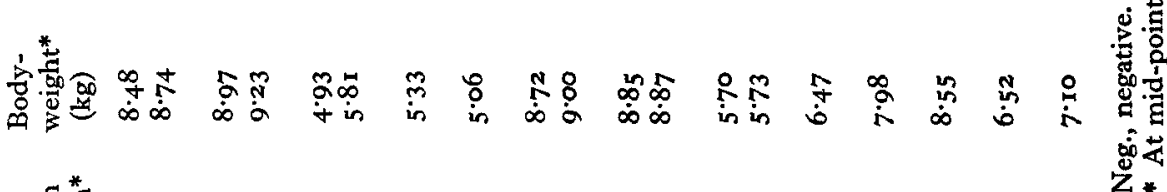

要莺

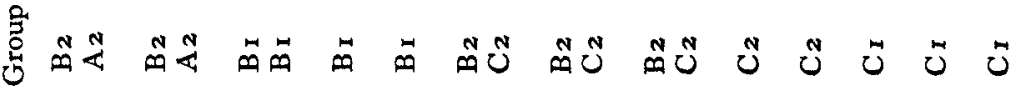

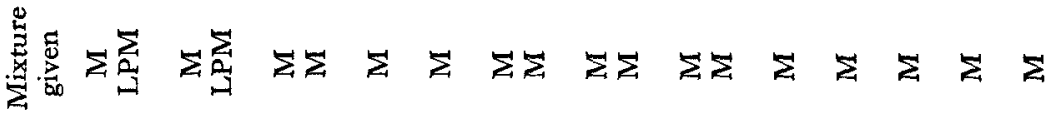

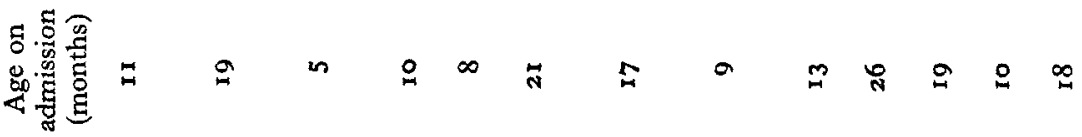

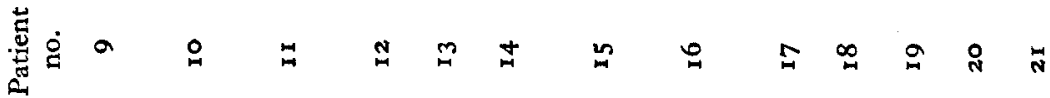


EXPERIMENTAL

Subjects

The subjects were twenty-one male Jamaican infants recovering from severe malnutrition, of whom ten were given leaf protein. Their ages ranged from 5 to 26 months (Table I). The clinical characteristics of infantile malnutrition in Jamaica have been described in previous reports (Waterlow, I948; Jelliffe, Bras \& Stuart, I954). Measurement of balance was in general not begun until a month or more after the babies had been admitted to hospital; by this time they were taking food well and beginning to gain weight, although they were still far below the normal weight for their age. The mean weight at the mid-point of the balances was $56 \%$ of the USA standard (Nelson, 1954).

\section{Methods}

The milk diets were made up of dried skim milk, sugar, starch and arachis oil (Waterlow \& Wills, I960; Waterlow, I96r). They provided daily various amounts of protein $(7.5-3 \circ \mathrm{g})$ and about $900 \mathrm{kcal} / \mathrm{l}$. The leaf-protein concentrates were kindly supplied by Mr N. W. Pirie, FRS, of Rothamsted Experimental Station, Harpenden, Herts., either as a wet frozen block or as a freeze-dried powder. They were incorporated in the diets in place of an equivalent amount of dried skim milk, to give a final protein content of about $3 \circ \mathrm{g} / \mathrm{l}$, in which $50-70 \%$ of the $\mathrm{N}$ was derived from LP.

Enough of a mixture was made up at any one time to provide feeds for $48 \mathrm{~h}-$ usually a volume of 21 . The $\mathrm{N}$ content of each batch was measured by the microKjeldahl method. Protein was calculated as $\mathrm{N} \times 6 \cdot 25$. The calorie content of each mixture was calculated from its composition, with factors of $4 \mathrm{kcal} / \mathrm{g}$ for protein and carbohydrate, and $9 \mathrm{kcal} / \mathrm{g}$ for oil.

With one exception, each balance on a given mixture consisted of at least two and usually three 2-day collection periods, with a day of rest in between. Before balance measurements were begun the diet was given for an initial period of at least 3 days.

All the mixtures were liquid, and were given from a cup. The intake was measured by two methods: $(a)$ for all feeds, by weighing the cup before and after the feed; $(b)$ for most, but not all, feeds, by weighing the baby before and after the feed, together with any urine or stool passed. A comparison of the results for 800 feeds in which both methods were used showed that method $(a)$ overestimated the intake as assessed by method $(b)$ by an average of $2 \cdot 1 \%$ (see p. 539 ).

Urine was collected by a finger-cot attached to the penis, and acidified with sulphuric acid. Stools were collected on pads of absorbent cotton wool, which were then thoroughly soaked and mixed in dilute acid. It was found in preliminary experiments that this simple method gives complete recovery. It was not considered necessary to use stool markers, since the babies passed faeces two or three times a day. The methods have been described in detail in a previous paper (Waterlow \& Wills, 1960). 


\section{Experimental design}

The diets fall into three categories:

(A) Leaf protein + milk protein (LPM). The intakes ranged from 390-950 mg N/kg body-weight daily. The trials have been arbitrarily divided into two subgroups, A I and $\mathrm{A}_{2}$, according to whether the intakes were greater or less than $600 \mathrm{mg} \mathrm{N} / \mathrm{kg}$ day.

(B) Milk at levels of $\mathrm{N}$ intake which were matched as closely as possible with those in group A. The range was from 340 to $1000 \mathrm{mg} \mathrm{N} / \mathrm{kg}$ body-weight daily. The trials have again been divided into two subgroups, $\mathrm{B}_{\mathrm{I}}$ and $\mathrm{B}_{2}$, with the dividing line at $\mathrm{N}$ intake of $600 \mathrm{mg} / \mathrm{kg}$ day.

(C) Milk at low levels of $\mathrm{N}$ intake, ranging from 137 to $254 \mathrm{mg} / \mathrm{kg}$ body-weight daily. The trials have been divided into two subgroups, $\mathrm{C}_{\mathbf{I}}$ and $\mathrm{C}_{2}$, according to whether the intakes were greater or less than $200 \mathrm{mg} \mathrm{N} / \mathrm{kg}$ day.

For brevity, diets in groups $\mathrm{B}$ and $\mathrm{C}$ are referred to simply as 'milk', although strictly they were milk mixtures.

The details of the trials that were made with each patient are shown in Table I. The main part of the study was concerned with the comparison of LPM and milk at approximately equal protein intakes ( $\mathrm{A}$ I and $\mathrm{A} 2$ versus $\mathrm{B}$ I and $\mathrm{B}$ 2). This comparison was made with ten subjects (nos. I-IO, Table I). With three of these ten babies balance measurements were also done at low levels of protein intake (subjects 3,4 and 5 ).

In order to enlarge the number of control subjects, values have been included for eleven additional babies given milk mixtures alone. Three of them had high protein intakes (nos. I1, 12, 13); five had low protein intakes (nos. 17-21). With the remaining three (nos. 14, 15, I6) high and low intakes were compared.

The order in which the diets were given is also shown in Table $\mathrm{x}$. The order was important, because it has been shown previously that in human subjects, as in animals, the amount of $\mathrm{N}$ retained is influenced by the extent of body protein depletion at the time of the balance test (Allison, I 95 I ; Waterlow \&Wills, I960). In children recovering rapidly from malnutrition this factor may alter significantly in as little as I0-14 days. Therefore to make the comparison as fair as possible, milk was given before LPM to four patients, after LPM to two, and both before and after to four.

\section{Definitions}

$\mathrm{N}$ absorbed was calculated as $\mathrm{N}$ intake - faecal $\mathrm{N}$.

Percentage absorption $=\frac{\mathrm{N} \text { intake }- \text { faecal } \mathrm{N}}{\mathrm{N} \text { intake }} \times 100$.

No corrections have been made for faecal metabolic $\mathrm{N}$.

$\mathrm{N}$ retained was calculated as $\mathrm{N}$ absorbed - urinary $\mathrm{N}$.

Percentage retention $=\frac{\mathrm{N} \text { intake }-(\text { faecal } \mathrm{N}+\text { urinary } \mathrm{N})}{\mathrm{N} \text { intake }} \times$ Ioo. 


\section{RESULTS}

\section{Leaf protein}

The leaf-protein mixtures were well accepted by the babies, who appeared to have no objection to the green colour or to the slight taste of grass. There were no gastrointestinal disturbances, other than mild constipation in some subjects. Two babies, both of whom were receiving a mixture of wheat-leaf protein, developed painful erythema and swelling of the soles of the feet, with itching erythematous nodules on the legs. In one, the left hand and left side of the face were also swollen. These were probably allergic reactions, since they responded rapidly to treatment with antihistamine drugs. There were no systemic effects.

Table 2. Mean values with their standard errors for absorption and retention of nitrogen by malnourished infants from mixtures of leaf protein and milk (LPM) compared with values for infants given milk $(M)$ alone

\begin{tabular}{|c|c|c|}
\hline \multicolumn{3}{|c|}{ (Subjects I-ro of Table I) } \\
\hline & LPM & $\mathrm{M}$ \\
\hline No. of trials & IO & I4 \\
\hline $\begin{array}{l}\text { Time of trial (days from } \\
\text { admission)* }\end{array}$ & $5 x$ & 45 \\
\hline $\begin{array}{l}\text { Weight* of subjects as percentage } \\
\text { of standard } \dagger\end{array}$ & $59 \cdot 3$ & $57^{\circ} 9$ \\
\hline Weight gain ( $\mathrm{g} / \mathrm{kg}$ day) & $4 \cdot 3$ & $5 \cdot 4$ \\
\hline Calorie intake (kcal/kg day) & 143 & $\mathbf{I} 5 \mathbf{I}$ \\
\hline $\mathrm{N}$ intake (mg/kg day) & 630 & 631 \\
\hline $\begin{array}{l}\mathrm{N} \text { absorbed: } \\
\mathrm{mg} / \mathrm{kg} \text { day } \\
\text { as percentage of intake } \\
\mathrm{N} \text { retained: }\end{array}$ & $\begin{array}{l}519 \\
83 \cdot 3 \pm I \cdot 95\end{array}$ & $\begin{array}{l}556 \\
88 \cdot 3 \pm 0 \cdot 92\end{array}$ \\
\hline $\begin{array}{l}\mathrm{mg} / \mathrm{kg} \text { day } \\
\text { as percentage of intake } \\
\text { as percentage of } \mathrm{N} \text { absorbed }\end{array}$ & $\begin{array}{l}203 \\
32 \cdot 0 \pm 1 \cdot 38 \\
38 \cdot 5 \pm 1 \cdot 59\end{array}$ & $\begin{array}{l}234 \\
35 \cdot 5 \pm 3 \cdot 85 \\
40 \cdot 1 \pm 4 \cdot 37\end{array}$ \\
\hline
\end{tabular}

The balance results are shown in full in Table $\mathrm{I}$. The percentage retention varied rather widely, with no clear relation to the absolute level of $\mathrm{N}$ intake. The amounts of $\mathrm{N}$ retained were of the same order of magnitude as those found in an earlier study in Jamaica (Waterlow \& Wills, I960), and by others working on malnourished children. They were much greater than the amounts retained by normal children.

Table 2 summarizes the results of the comparison between LPM and milk. The range of $\mathrm{N}$ intake in different subjects was fairly large, but for each subject the intake on the two diets was very nearly the same. In the series as a whole the conditions of the comparison were closely matched not only for $\mathrm{N}$ intake but for calorie intake, time after admission to hospital, and degree of weight deficit at the time when the balances 
were done. All these factors are important if results are to lend themselves to comparison. If anything, they gave a small advantage to the milk diet, since the balance measurements in group B were made at a slightly earlier stage of recovery, when the deficit in body-weight was a little greater.

Accurate measurements of growth cannot be made over the short period of a balance study. There was therefore much variation, but on average the gains on LPM were as good as those on milk at equal protein intakes. On both diets the gains were somewhat less than the 'predicted' gains calculated from the intakes of protein and calories (Waterlow, I96I). This calculation is based on findings with infants given different milk diets over longer periods, without balance measurements. It is possible that the immobilization imposed by the balance trial was a retarding factor. One baby who continued to receive approximately half his protein intake from LPM for 20 days after his balance trial had ended gained $\mathrm{r} \cdot 2 \mathrm{~kg}$, or $10.6 \mathrm{~g} / \mathrm{kg}$ day, which was one and a half times the predicted rate of gain (Waterlow \& Cruickshank, 196r).

Absorption of $\mathrm{N}$ was less efficient from LPM than from milk.

When the results within subjects are compared, ${ }^{*}$ the mean difference in percentage absorption (LPM-milk) was $-5.4 \%$ (SEM $\pm 1 \cdot 59)$. This difference is significant $(P<0.01)$.

$\mathrm{N}$ retention was also a little less on LPM. The mean difference in percentage retention (LPM - milk) within subjects was $-1 \cdot 15 \%$ (SEM $\pm 4 \cdot 7)$. This difference is not significant.

Derived values have been calculated on the assumption that, when milk and LP are given together, the milk protein is absorbed and retained to the same extent as when milk is given alone. Obviously this assumption is only an approximation; moreover, any errors in the results for milk alone will cause contrary errors in the calculated figures for leaf protein alone.

The calculated mean absorption for LP alone was $79.8 \%$, compared with $88.7 \%$ for milk. Within subjects the mean difference in absorption (LP-milk) was $-8.9 \%$ (SEM \pm 2.57$)$. This difference is significant $(P<0.01)$. The calculated mean retention for LP alone was $31 \cdot 6 \%$, compared with $34^{\circ} \mathrm{I} \%$ for milk. The mean difference (LP-milk) within subjects was $-2.5 \%$, which is not significant.

\section{Low protein intakes}

The results for children receiving only small amounts of protein derived entirely from milk with no LP supplement are shown in Table 3 (group C). This table summarizes all the findings for all the groups in relation to protein intake.

The measurements on low-protein milk diets fell into two subgroups, in which the mean protein intakes were approximately $\mathrm{I}$ and $\mathrm{I} \cdot 5 \mathrm{~g} / \mathrm{kg}$ day. In both, the apparent absorption was reduced because no allowance has been made for faecal metabolic $\mathrm{N}$, which becomes significant at these low levels of intake. At both levels there were small positive $\mathrm{N}$ balances, but in each subgroup one child was in negative balance. Previous experience (Waterlow \& Wills, I960) suggests that in the malnourished state $\mathrm{N}$ is used

* When, as in subjects $\mathrm{I}-4$ (Table $\mathrm{I}$ ), there were two trials with milk at high or moderate intakes, and only one with LPM, the results for the two periods on milk have been averaged. 
more economically, so that retention is increased at low levels of intake. The conditions for achieving positive balance were therefore favourable. Nevertheless, in neither subgroup was the mean amount of $\mathrm{N}$ retained significantly different from zero. Therefore, as far as the results in this small series go, an intake of $240 \mathrm{mg} \mathrm{N} / \mathrm{kg}$ day, or $\mathrm{I} \cdot 5 \mathrm{~g}$ protein $/ \mathrm{kg}$ day cannot be regarded as adequate for maintenance, let alone for growth, in children of this age. On the other hand, when the $\mathrm{N}$ intake was doubled by the addition of leaf protein, highly significant positive balances were achieved. From these results it seems that leaf protein can act as a valuable supplement to a marginal intake of milk.

\section{DISCUSSION}

Conclusions drawn from $\mathrm{N}$ balance experiments have been criticized on the grounds that positive balances are often found that cannot be explained by parallel gains in body-weight (Holmes, Jones, Lyle \& Stanier, I956; Wallace, I959; Gordon \& Ganzon, 1959). From the experimental evidence (Wallace, 1959) it is not acceptable to postulate an increased $\mathrm{N}$ concentration in the body. Therefore the positive balances must be fallacious. Wallace (1959) has pointed out that in the balance technique the errors are additive; if the measurement of intake is incomplete, as may easily happen in infants because of regurgitation and dribbling, and if there are any losses in collection of urine and faeces, the combined effects may cause a very large error in the calculated retention.

Table 3. Mean values for absorption and retention of nitrogen by malnourished infants at different levels of protein intake from milk $(M)$ or leaf protein and milk mixture $(L P M)$

\begin{tabular}{|c|c|c|c|c|c|c|}
\hline Group $\ldots$ & $A_{I}$ & $\mathrm{~B} \mathrm{I}_{\mathrm{I}}$ & $\mathrm{A}_{2}$ & $\mathrm{~B}_{2}$ & $\mathrm{C}_{\mathbf{I}}$ & $\mathrm{C}_{2}$ \\
\hline Diet & LPM & M & LPM & $\mathbf{M}$ & $\mathbf{M}$ & $\mathbf{M}$ \\
\hline No. of trials & 5 & II & 5 & IO & 5 & 6 \\
\hline $\begin{array}{l}\text { Weight gain } \\
\text { ( } g / k g \text { day) }\end{array}$ & $5 \cdot 2$ & 5.4 & $3 \cdot 4$ & $3 \cdot 6$ & $3 \cdot 2$ & $2 \cdot 25$ \\
\hline $\begin{array}{r}\text { Calorie intake } \\
\text { (kcal/kg day) }\end{array}$ & 146 & ${ }_{15}^{8}$ & 140 & I26 & I 37 & 126 \\
\hline $\begin{array}{l}\mathrm{N} \text { intake } \\
(\mathrm{mg} / \mathrm{kg} \text { day })\end{array}$ & 765 & 776 & 496 & 504 & $23^{8}$ & 166 \\
\hline $\begin{array}{l}\mathrm{N} \text { absorbed: } \\
\mathrm{mg} / \mathrm{kg} \text { day } \\
\text { as percentage } \\
\text { of intake }\end{array}$ & $\begin{array}{l}602 \\
78 \cdot 7\end{array}$ & $\begin{array}{l}690 \\
89 \cdot I\end{array}$ & $\begin{array}{l}436 \\
87 \cdot 9\end{array}$ & $\begin{array}{l}452 \\
89 \cdot 9\end{array}$ & $\begin{array}{c}188 \\
78 \cdot 8\end{array}$ & $\begin{array}{l}139 \\
83.5\end{array}$ \\
\hline $\begin{array}{l}\mathrm{N} \text { retained: } \\
\mathrm{mg} / \mathrm{kg} \text { day } \\
\text { as percentage } \\
\text { of intake }\end{array}$ & $\begin{array}{l}246 \\
32 \cdot I\end{array}$ & $\begin{array}{l}276 \\
35^{\cdot I}\end{array}$ & $\begin{array}{l}160 \\
3 I^{*} 9\end{array}$ & $\begin{array}{l}165 \\
32 \cdot 0\end{array}$ & $\begin{array}{l}45 \\
18 \cdot 3\end{array}$ & $\begin{array}{l}31 \\
17 \cdot 0\end{array}$ \\
\hline $\begin{array}{l}\text { as percentage } \\
\text { of } N \text { absorbed }\end{array}$ & $40 \cdot 7$ & $39 \cdot 6$ & $36 \cdot 3$ & $35 \cdot 3$ & $22 \cdot 0$ & $19 \cdot 3$ \\
\hline
\end{tabular}

However, the force of this argument varies with the conditions of the balance study. For arithmetical reasons the errors will be greatest when the $\mathrm{N}$ intake is high and the expected retention low, as in the normal European or North American infant on cow's milk. A normal baby of I year should retain daily about $40 \mathrm{mg} \mathrm{N} / \mathrm{kg}$ body-weight. 
If the intake is $3 \mathrm{~g}$ protein, or about $500 \mathrm{mg} \mathrm{N} / \mathrm{kg}$ body-weight, additive errors of $5 \%$ in the measurement of both intake and output will more than double the figure for retention.

The situation is much more favourable when, as in earlier studies in this Unit (Waterlow \& Wills, 1960), intakes are lower, and measurements are made on malnourished infants who presumably retain larger amounts of $\mathrm{N}$, since they are gaining weight at several times the normal rate. Such a child might easily gain daily $5 \mathrm{~g} / \mathrm{kg}$ (Waterlow, I96I). If this is balanced 'tissue', with $\mathrm{N}$ content of $2.5 \%$ (Stearns, Newman, McKinley \& Jeans, 1958), the expected daily retention would be $125 \mathrm{mg}$ $\mathrm{N} / \mathrm{kg}$. If the daily intake is $300 \mathrm{mg} \mathrm{N} / \mathrm{kg}$, additive errors at the level of $5 \%$ amount to only a small fraction of the $\mathrm{N}$ retained.

Table 4. Mean values, with their standard errors, for the nitrogen retentions given in Table 3 , adjusted on the assumption of an error of $5 \%$ in the measurement of intake and $10 \%$ in the collection of urine and faeces

$\begin{array}{ccccc}\text { Group } & \text { Diet } & \begin{array}{c}\text { N intake } \\ (\mathrm{mg} / \mathrm{kg} \text { day) }\end{array} & \begin{array}{c}\text { N retained } \\ (\mathrm{mg} / \mathrm{kg} \text { day) }\end{array} & \begin{array}{c}\text { N retained } \\ \text { as percentage } \\ \text { of intake }\end{array} \\ \mathrm{A}_{1} & \mathrm{LPM} & 727 & 156 \pm 2 \mathrm{I}^{\circ} \cdot 4 & 2 \mathrm{2} \cdot 4 \pm \mathrm{I} \cdot 8 \\ \mathrm{~B}_{1} & \mathrm{M} & 743 & 175 \pm 32 \cdot 9 & 23 \cdot 9 \pm 3 \cdot 6 \\ \mathrm{~A}_{2} & \mathrm{LPM} & 47 \mathrm{I} & 105 \pm 16 \cdot 5 & 2 \mathrm{I} \cdot 2 \pm 2 \cdot 5 \\ \mathrm{~B}_{2} & \mathrm{M} & 49 \mathrm{I} & 108 \pm 19 & 22 \cdot 4 \pm 4 \cdot 3 \\ \mathrm{C}_{1} & \mathrm{M} & 246 & 14 \pm 20 \cdot 7 & 5 \cdot 4 \pm 9 \cdot 3 \\ \mathrm{C}_{2} & \mathrm{M} & 159 & 13 \pm 17 \cdot 1 & 6 \cdot 2 \pm 1 \mathrm{I} \cdot 9\end{array}$

M, milk; LPM, leaf protein and milk mixture.

Difficulties again arise when intakes are marginal for determination of minimal requirements. Here the expected retentions are small, and although the intakes are low, errors at the level of $5 \%$ are enough to convert a negative into a positive balance, and so to be seriously misleading.

It is difficult to estimate how great the errors in fact are. Intakes can be checked by test-weighing the baby before and after feeds. This was done in the later part of this work, as a check on the standard method of weighing the feeding mug. In eighty 2-day periods, in each of which there were ten test feeds, the mean difference between results by the two methods was $2 \cdot \mathrm{I} \%$. Losses of faeces affect the figure for absorption, but have little effect on the figure for retention, as the faecal $\mathrm{N}$ amounts to only IO-I $5 \%$ of the total N. I have at present no accurate means of checking the completeness of urine collections. Creatinine output fluctuates more than that of N, but the mean $24 \mathrm{~h}$ output of rehabilitated babies in my ward closely approaches that of normal infants in the USA (Stearns et al. 1958; Standard, Wills \& Waterlow, 1959) which suggests that there is no large systematic error, if the American results are correct. In the average 2-day balance period a loss of $10 \%$ of the urine would amount to more than $100 \mathrm{ml}$, which would not go undetected. However, to be on the safe side, the figures in Table 3 have been recalculated on the assumption that there was an error of $5 \%$ 
in the measurement of intake and a loss of $10 \%$ in the collection of excreta-these errors to be additive.

The results so adjusted are shown in Table 4 . With the low protein intakes, $\mathrm{N}$ retention was negligible. With the medium intakes (groups A2, B2) providing about $3 \mathrm{~g}$ protein/kg daily, the retentions were highly significant, at a level that should be adequate for growth as well as for maintenance. In fact, on these intakes the children gained weight satisfactorily, although not at the maximum rate possible. The calculated $\mathrm{N}$ content of the tissue gained was 2.8 and $2.9 \%$ in groups $\mathrm{A}_{2}$ and $\mathrm{B}_{2}-$-figures that agree well with the theoretical.

It seems that the application of this adjustment does not alter the general conclusions drawn from the uncorrected figures. However, there were too few subjects for accurate quantitative estimates to be made of the intakes needed for growth and for maintenance.

\section{SUMMARY}

I. Nitrogen balance studies were made on ten Jamaican infants who were recovering from malnutrition but were still seriously underweight.

2. Three diets were used: (A) mixtures of leaf-protein concentrates and milk, providing daily $3-5 \mathrm{~g}$ protein $/ \mathrm{kg}$ body-weight, in which one-half to one-third of the $\mathrm{N}$ was derived from the leaf protein; (B) a milk diet of equal protein content; (C) an unsupplemented milk diet providing daily $0.9-\mathrm{r} \cdot 6 \mathrm{~g}$ protein $/ \mathrm{kg}$.

3. The mean gains in weight of the babies on leaf protein-milk mixtures were as good as those of babies on milk at equal protein levels.

4. There was evidence that $\mathrm{N}$ from leaf protein was less well absorbed than that from milk; there was no significant difference in retention of $\mathrm{N}$ from the two sources.

5. The results suggest that leaf protein could act as a valuable supplement to marginal intakes of milk.

6. The errors involved in balance studies of this kind are discussed.

\section{REFERENCES}

Allison, J. B. (1951). Fed. Proc. ro, 676.

Duckworth, J., Hepburn, W. R. \& Woodham, A. A. (1961). F. Sci. Fd Agric. 12, I6.

Duckworth, J. \& Woodham, A. A. (I96r). F. Sci. Fd Agric. 12, 5.

Gordon, H. H. \& Ganzon, A. F. (1959). F. Pediat. 54, 503.

Holmes, E. G., Jones, E. R., Lyle, M. D. \& Stanier, M. W. (1956). Brit. F. Nutr. ro, I98.

Jelliffe, D. B., Bras, G. \& Stuart, K. L. (I954). West Indian med. F. 3, 43 .

Morrison, J. E. \& Pirie, N. W. (1961). F. Sci. Fd Agric. 12, r.

Nelson, W. E. (editor) (1954). Textbook of Pediatrics, 6th ed. Vol. 4, p. 13. Philadelphia: W. B. Saunders Co.

Standard, K. L., Wills, V. G. \& Waterlow, J. C. (г959). Amer. F. clin. Nutr. 7, 27 I.

Stearns, G., Newman, K. J., McKinley, J. B. \& Jeans, P. C. (1958). Ann. N.Y. Acad. Sci. 69, 857.

Wallace, W. M. (1959). Fed. Proc. 18, I 125.

Waterlow, J. C. (1948). Spec. Rep. Ser. med. Res. Coun., Lond., no. 263.

Waterlow, J. C. (1961). F. trop. Pediat. 7, г6.

Waterlow, J. C. \& Cruickshank, E. K. (1961). Publ. nat. Res. Coun., Wash., no. 843, p. 69.

Waterlow, J. C. \& Wills, V. G. (1960). Brit. F. Nutr. 14, I83. 